\title{
Severe Acute Cholangitis and Bacteremia Due to Campylobacter jejuni: A Case Report and Review of the Literature
}

\author{
Kento Shionoya ${ }^{1}$, Ryosuke Tonozuka ${ }^{1}$, Takao Itoi ${ }^{1}$, Atsushi Sofuni ${ }^{1}$, Takayoshi Tsuchiya ${ }^{1}$, \\ Kentaro Ishii ${ }^{1}$, Reina Tanaka ${ }^{1}$, Shuntaro Mukai ${ }^{1}$, Kazumasa Nagai ${ }^{1}$, \\ Kenjiro Yamamoto ${ }^{1}$ and Itaru Nakamura ${ }^{2}$
}

\begin{abstract}
:
Campylobacter jejuni is common cause of enteritis, but biliary infection rarely reported. An 82-year-old woman with pancreatic head cancer underwent endoscopic biliary drainage for malignant biliary obstruction. She was subsequently admitted for management of diarrhea. C. jejuni was identified in stool culture. Her symptoms resolved temporarily without antibiotics but flared up with a fever a few days later. She was diagnosed with acute cholangitis and bacteremia with $C$. jejuni. Endoscopic biliary drainage and antimicrobial administration improved her symptoms. As complications of $C$. jejuni diarrhea are rare, antibiotics are not necessarily indicated but sometimes are needed to prevent complications.
\end{abstract}

Key words: Campylobacter jejuni, acute cholangitis, Campylobacter species, Campylobacter enteritis

(Intern Med 60: 3737-3741, 2021)

(DOI: 10.2169/internalmedicine.7380-21)

\section{Introduction}

Campylobacter jejuni is a Gram-negative bacillus that may be curved or spiral-shaped and is a common cause of bacterial enteritis. Biliary infection caused by Campylobacter species rarely leads to bacteremia, but the risk of biliary infection is increased in patients who are elderly and those with underlying disease, such as cancer, human immunodeficiency virus infection, or diabetes.

We herein report a case of acute cholangitis and bacteremia following $C$. jejuni enteritis.

\section{Case Report}

An 82-year-old woman diagnosed with cancer of the head of the pancreas had undergone endoscopic biliary drainage and placement of a fully covered self-expandable metal stent with an antimigration system (Duckbill Biliary Stent,
Kawasumi Laboratory, Tokyo, Japan) (1) for malignant biliary obstruction 1 month earlier. She had declined antitumor treatment, including chemotherapy, and was being followed up in an outpatient clinic.

After the stent placement, she visited our hospital because of general weakness and a one-week history of persistent severe watery diarrhea. A stool sample was taken for culture, and probiotics were recommended. By the time the causative bacterial species was identified, the patient's symptoms had resolved. Therefore, no antibiotic treatment was provided. A few days later, she developed influenza A infection with a high-grade fever of approximately $39^{\circ} \mathrm{C}$ and generalized sharp jolts of pain due to physical contact. She was treated with oseltamivir phosphate, and the fever resolved temporarily but returned 15 days later, accompanied by abdominal pain and persistent watery diarrhea.

Laboratory tests showed elevated hepatobiliary enzyme levels (aspartate aminotransferase, $41 \mathrm{U} / \mathrm{L}$; alkaline phosphatase, $574 \mathrm{U} / \mathrm{L}$; gamma-glutamyl transpeptidase, $138 \mathrm{U} /$

${ }^{1}$ Department of Gastroenterology and Hepatology, Tokyo Medical University, Japan and ${ }^{2}$ Department of Infection Prevention and Control, Tokyo Medical University, Japan 


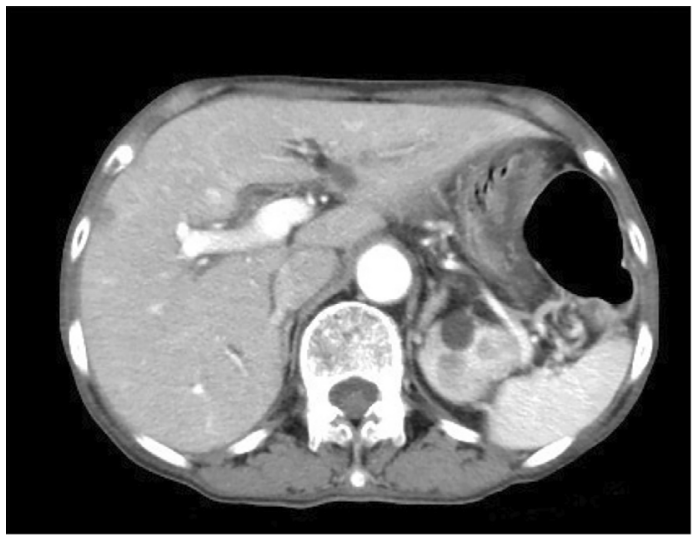

(A)

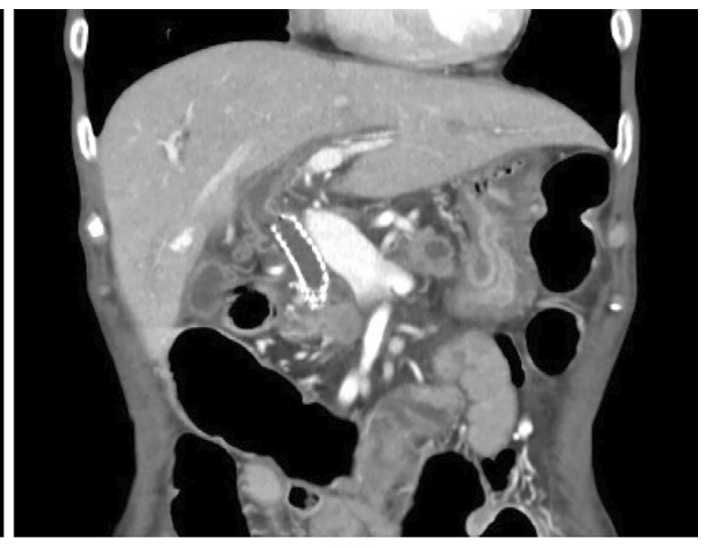

(B)

Figure 1. Abdominal contrast-enhanced computed tomography scans obtained at the onset of acute cholangitis. (A) Intrahepatic bile ducts are dilated. (B) The fully covered self-expandable metal stent is not obstructed and is appropriately positioned in the common bile duct. There was no wall thickening of the gallbladder or enlargement of the gallbladder.

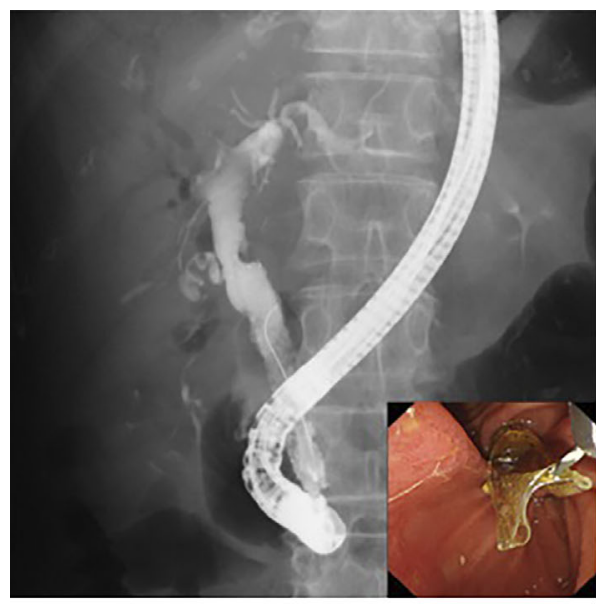

(A)

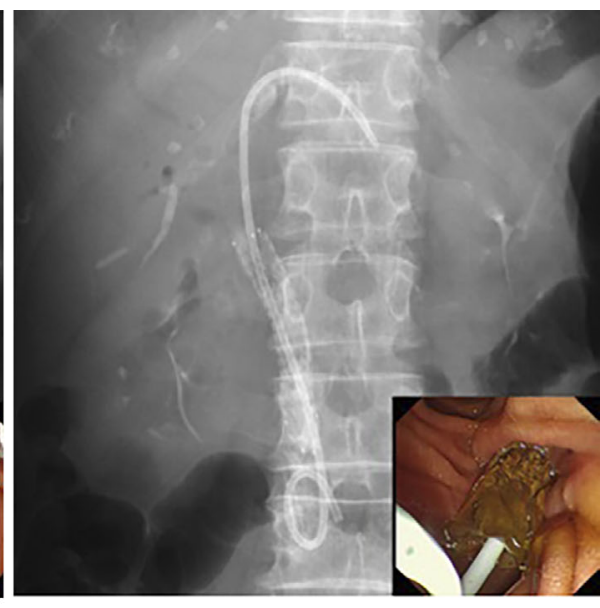

(B)

Figure 2. Endoscopic retrograde cholangiopancreatography for additional biliary drainage. (A) Cholangiography shows no stent dysfunction, such as obstruction or migration. (B) Endoscopy shows discharge of purulent bile from the self-expandable metal stent.

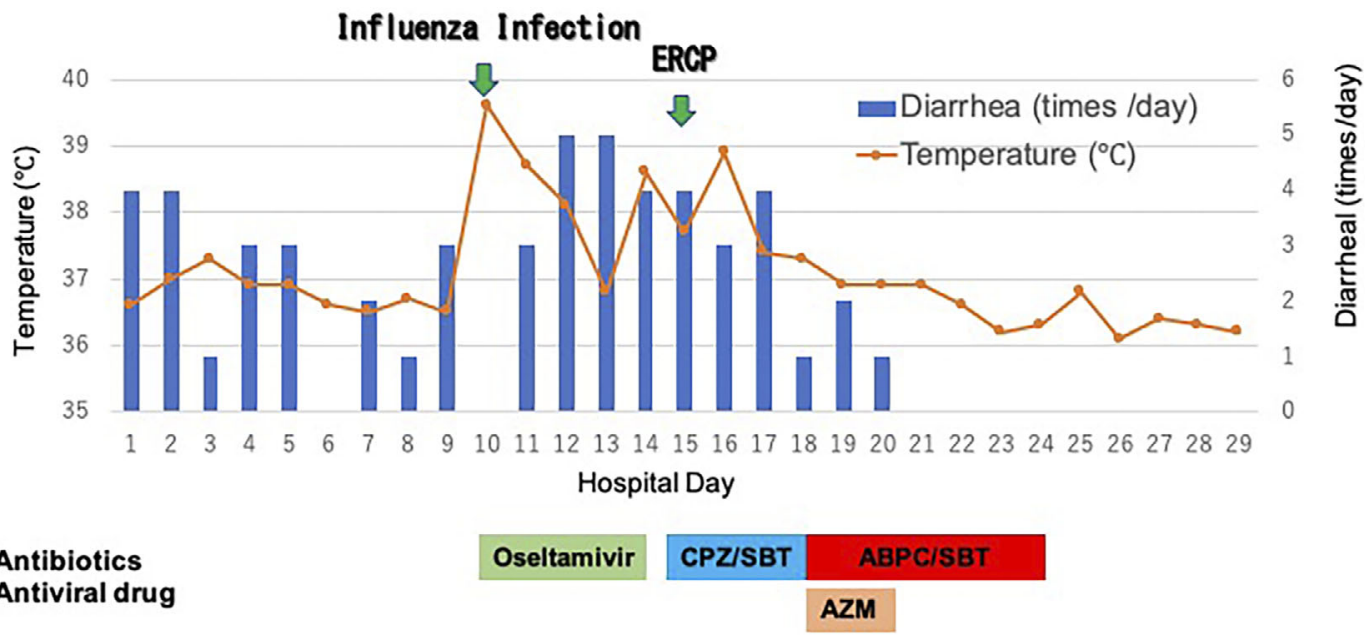

Figure 3. The patient's clinical course. ERCP: endoscopic retrograde cholangiopancreatography, CPZ/SBT: cefoperazone/sulbactam, ABPC/SBT: ampicillin-sulbactam, AZM: azithromycin and ampicillin-sulbactam 
Table. Reports of Biliary Infection with Campylobacter Species.

\begin{tabular}{|c|c|c|c|c|c|c|c|}
\hline Reference & $\begin{array}{l}\text { Age }(\mathrm{y}) / \\
\text { Sex }\end{array}$ & $\begin{array}{l}\text { Biliary } \\
\text { infection }\end{array}$ & Bacterial name & $\begin{array}{l}\text { Preceding } \\
\text { enteritis }\end{array}$ & Bacteremia & Underlying disease & Treatment \\
\hline 11 & $11 / \mathrm{M}$ & $\begin{array}{c}\text { Acute } \\
\text { cholecystitis }\end{array}$ & C. jejuni & No & None & None & $\begin{array}{l}\text { Antibiotics and } \\
\text { operation }\end{array}$ \\
\hline 11 & $60 / \mathrm{F}$ & $\begin{array}{c}\text { Acute } \\
\text { cholecystitis }\end{array}$ & C. jejuni & No & None & Obstructive jaundice & Operation \\
\hline 11 & $32 / \mathrm{F}$ & $\begin{array}{l}\text { Acute } \\
\text { cholecystitis }\end{array}$ & C. jejuni & Yes & None & None & Operation \\
\hline 12 & $52 / \mathrm{F}$ & $\begin{array}{c}\text { Acute } \\
\text { cholecystitis }\end{array}$ & C. jejuni & Yes & None & $\begin{array}{c}\text { Cholecystolithiasis, chronic } \\
\text { cholecystitis }\end{array}$ & $\begin{array}{l}\text { Antibiotics and } \\
\text { operation }\end{array}$ \\
\hline 13 & NA & $\begin{array}{c}\text { Acute } \\
\text { cholecystitis }\end{array}$ & C. jejuni & No & None & None & Operation \\
\hline 14 & $24 / \mathrm{M}$ & $\begin{array}{c}\text { Acute } \\
\text { cholecystitis }\end{array}$ & $\begin{array}{l}\text { Campylobacter } \\
\text { sp. }\end{array}$ & No & None & HIV & $\begin{array}{l}\text { Antibiotics and } \\
\text { operation }\end{array}$ \\
\hline 15 & $46 / F$ & $\begin{array}{c}\text { Acute } \\
\text { cholecystitis }\end{array}$ & $\begin{array}{l}\text { Campylobacter } \\
\text { sp. }\end{array}$ & No & None & None & Operation \\
\hline 16 & $55 / \mathrm{M}$ & $\begin{array}{c}\text { Acute } \\
\text { cholecystitis }\end{array}$ & $\begin{array}{l}\text { Campylobacter } \\
\text { sp. }\end{array}$ & No & None & None & $\begin{array}{l}\text { Antibiotics and } \\
\text { operation }\end{array}$ \\
\hline 17 & $74 / \mathrm{M}$ & $\begin{array}{l}\text { Acute } \\
\text { cholangitis }\end{array}$ & C. fetus & No & None & Choledocholith & $\begin{array}{c}\text { Antibiotics and } \\
\text { endoscopic drainage }\end{array}$ \\
\hline 18 & $62 / \mathrm{M}$ & $\begin{array}{c}\text { Acute } \\
\text { cholecystitis }\end{array}$ & $\begin{array}{l}\text { Campylobacter } \\
\text { sp. }\end{array}$ & No & None & None & $\begin{array}{l}\text { Antibiotics and } \\
\text { operation }\end{array}$ \\
\hline 19 & $84 / \mathrm{F}$ & $\begin{array}{c}\text { Acute } \\
\text { cholecystitis }\end{array}$ & C. jejuni & Yes & None & None & $\begin{array}{l}\text { Antibiotics and } \\
\text { operation }\end{array}$ \\
\hline 20 & $59 / \mathrm{M}$ & $\begin{array}{c}\text { Acute } \\
\text { cholecystitis }\end{array}$ & C. jejuni & No & None & None & $\begin{array}{l}\text { Antibiotics and } \\
\text { operation }\end{array}$ \\
\hline 21 & $83 / \mathrm{M}$ & $\begin{array}{c}\text { Acute } \\
\text { cholecystitis }\end{array}$ & C. jejuni & Yes & None & None & $\begin{array}{l}\text { Antibiotics and } \\
\text { operation }\end{array}$ \\
\hline 22 & $64 / \mathrm{F}$ & $\begin{array}{c}\text { Acute } \\
\text { cholecystitis }\end{array}$ & C. fetus & No & None & $\begin{array}{l}\text { Hepatocellular carcinoma, } \\
\text { obstructive jaundice }\end{array}$ & Antibiotics \\
\hline 23 & $62 / \mathrm{M}$ & $\begin{array}{c}\text { Acute } \\
\text { cholecystitis }\end{array}$ & C. jejuni & No & None & $\begin{array}{c}\text { Old myocardial infarction, } \\
\text { hypertension }\end{array}$ & $\begin{array}{l}\text { Antibiotics and } \\
\text { operation }\end{array}$ \\
\hline 24 & NA & $\begin{array}{c}\text { Acute } \\
\text { cholangitis }\end{array}$ & C. fetus & No & None & $\begin{array}{l}\text { Immune deficiency } \\
\text { syndrome }\end{array}$ & Antibiotics \\
\hline 25 & $51 / \mathrm{M}$ & $\begin{array}{c}\text { Acute } \\
\text { cholecystitis }\end{array}$ & C. jejuni & No & None & $\begin{array}{l}\text { Old myocardial infarction, } \\
\text { hypothyreosis, dyslipidemia }\end{array}$ & Operation \\
\hline 26 & $35 / \mathrm{M}$ & $\begin{array}{c}\text { Acute } \\
\text { cholecystitis }\end{array}$ & $\begin{array}{l}\text { Campylobacter } \\
\text { sp. }\end{array}$ & Yes & None & None & $\begin{array}{l}\text { Antibiotics and } \\
\text { operation }\end{array}$ \\
\hline 27 & $71 / \mathrm{M}$ & $\begin{array}{c}\text { Acute } \\
\text { cholecystitis }\end{array}$ & C. jejuni & No & None & $\begin{array}{l}\text { Hypertension, old } \\
\text { myocardial infarction }\end{array}$ & $\begin{array}{l}\text { Antibiotics and } \\
\text { operation }\end{array}$ \\
\hline 28 & $71 / \mathrm{M}$ & $\begin{array}{l}\text { Acute } \\
\text { cholangitis }\end{array}$ & C. showae & No & Existence & Biliary tract cancer & $\begin{array}{c}\text { Antibiotics and } \\
\text { endoscopic drainage }\end{array}$ \\
\hline 29 & $65 / \mathrm{M}$ & $\begin{array}{l}\text { Acute } \\
\text { cholecystitis }\end{array}$ & C. jejuni & No & None & $\begin{array}{l}\text { Non-Hodgkin's lymphoma, } \\
\text { cholelithiasis }\end{array}$ & Antibiotics \\
\hline Our case & $82 / \mathrm{F}$ & $\begin{array}{l}\text { Acute } \\
\text { cholangitis }\end{array}$ & C. jejuni & Yes & Existence & $\begin{array}{c}\text { Cancer of the pancreatic } \\
\text { head }\end{array}$ & $\begin{array}{c}\text { Antibiotics and } \\
\text { endoscopic drainage }\end{array}$ \\
\hline
\end{tabular}

C. jejuni: Campylobacter jejuni, C. fetus: Campylobacter fetus, C. showae: Campylobacter showae, HIV: human immunodeficiency virus

L), a low white blood cell count of $2,200 / \mathrm{mm}^{3}$, and a high C-reactive protein level of $3.1 \mathrm{mg} / \mathrm{dL}$. Abdominal contrastenhanced computed tomography showed dilated intrahepatic bile ducts with no wall thickening of the gallbladder or enlargement of the gallbladder (Fig. 1), as had been noted on previous computed tomography images. According to the 2018 Tokyo Guidelines, she was diagnosed with moderate acute cholangitis (2).

Endoscopic retrograde cholangiopancreatography showed that the stent was not obstructed but was discharging brownish, cloudy, purulent bile. The bile was cultured, a temporary plastic stent was placed for drainage (Fig. 2), and the patient was started on cefoperazone-sulbactam for cholangitis. After the replacement of an additional stent, her abdominal symptoms improved rapidly. The blood culture subsequently identified $C$. jejuni and the bile culture identified C. jejuni, Enterococcus casseliflavus, and Streptococcus anginosus. The antimicrobial therapy was switched to intravenous azithromycin for 5 days and ampicillin-sulbactam for 7 days. Thereafter, the fever and diarrhea resolved (Fig. 3).

\section{Discussion}

This was a rare case of acute cholangitis where the causa- 
tive organism was $C$. jejuni, which is a common cause of community-acquired bacterial enteritis. C. jejuni generally grows quite slowly, requiring 72-96 hours for primary isolation from stool samples and even longer from blood samples (3). Therefore, the symptoms and fever are likely to have already resolved by the time $C$. jejuni is identified in blood cultures from patients without underlying disease. As such, antibiotics are not always needed, but $C$. jejuni enteritis can become exacerbated, and bacteremia may develop as an extraintestinal complication, leading to acute biliary infection, pancreatitis, and peritonitis in rare cases (4).

Bacteremia occurs in $1 \%$ of $C$. jejuni infections (5-8), and biliary infection is very rare. Antibiotic therapy is needed in patients who are elderly, those who have serious underlying disease, and those who do not respond to conservative treatment $(9,10)$. In the present case, $C$. jejuni was identified on stool culture, and the infection appeared to resolve without antibiotics. A literature search revealed 23 cases of biliary infection caused by Campylobacter species in 21 reports (Table) (11-29). All cases caused by $C$. jejuni presented with acute cholecystitis, and all cases of acute cholangitis, except for our case, were caused by different species of the same genus. Most patients had an underlying biliary disorder, such as stones or malignancy, and a recent history of enteritis. Including our patient, there have been only two severe cases that led to bacteremia.

There are two possible pathways by which bacteremia could develop in patients with $C$. jejuni infection: the movement of $C$. jejuni from the intestinal tract into the biliary system and then into the blood vessels by cholangiovenous reflux (3) and direct bacterial translocation from the intestinal tract into the bloodstream independent of acute cholangitis (30). Given that the affinity of $C$. jejuni for vascular endothelium is lower than that of C. fetus (31), the C. jejuni bacteremia in our patient was likely induced by acute cholangitis. A self-expandable metallic stent with an antimigration system was used for biliary drainage under the expectation of long-term patency of the stent. Because of the rapid improvement in the patient's condition after placement of the additional biliary stent, the antimigration system may have interfered with biliary drainage and caused the severe bacteremia.

In conclusion, patients with an underlying biliary disorder and a history of $C$. jejuni enteritis should be monitored carefully for complications such as cholangitis and bacteremia.

The authors state that they have no Conflict of Interest (COI).

\section{References}

1. Kin T, Ishii K, Okabe Y, Itoi T, Katanuma A. Feasibility of biliary stenting to distal malignant biliary obstruction using a novel designed metal stent with duckbill-shaped anti-reflux valve. Dig Endosc 2020. Epub ahead of print. PMID: 32875614.

2. Kiriyama S, Kozaka K, Takada T, et al. Tokyo Guidelines 2018: diagnostic criteria and severity grading of acute cholangitis (with videos). J Hepatobiliary Pancreat Sci 25: 17-30, 2018.

3. Allos BM. Campylobacter jejuni infections: update on emerging issues and trends. Food Safety 32: 1201-1206, 2001.

4. Acheson D, Allos BM. Campylobacter jejuni infections: update on emerging issues and trends. Clin Infect Dis 32: 1201-1206, 2001.

5. Blaser MJ, Allos BM. Campylobacter jejuni and related species. In: Principles and Practice of Infectious Disease. 6th ed. Mandell GL, Bennett JE, Dolin R, Eds. Elsevier Churchill Livingstone, Philadelphia, 2005: 2548-2557.

6. Tee W, Kaldor J, Dwyer B. Epidemiology of Campylobacter diarrhea. Med J Aust 145: 499-503, 1986.

7. Skirrow MB, Jones DM, Sutcliffe E, Benjamin J. Campylobacter bacteremia in England and Wales, 1981-91. Epidemiol Infect 110: 567-573, 1993.

8. Heresy GP, et al. Campylobacter jejuni. In: Textbook of Pediatric Infectious Diseases. Saunders, Philadelphia, 2004: 1612-1621.

9. Douketis J, Low DE. Campylobacter fetus cholangitis and bacteremia. CMAJ 141: 925-926, 1989.

10. Kim Y, Shin JA, Han SB, Cho B, Jeong DC, Kang JH. Recurrent Campylobacter jejuni bacteremia in a patient with hypogammaglobinemia: A case report (Baltimore). Medicine 96: e2738, 2017.

11. Darling WM, Peel RN, Skirrow MB, Mulira JL. Campylobacter cholecystitis. Lancet 1: 1302, 1979.

12. Mertens A, De Smet M. Campylobacter cholecystitis. Lancet 1: 1092-1093, 1979.

13. Pereira Mde S, Lipton SD, Kim JK. Acute cholecystitis and Campylobacter fetus. Ann Intern Med 94: 821, 1981.

14. Costel EE, Wheeler AP, Gregg CR. Campylobacter fetus ssp fetus cholecystitis and relapsing bacteremia in a patient with acquired immunodeficiency syndrome. South Med J 77: 927-928, 1984.

15. Juliet C, Giglio M, Enríquez N. Extraintestinal infections due to Campylobacter. Report of 3 cases. Rev Med Chil 114: 140-142, 1986.

16. Verbruggen $\mathrm{P}$, Creve U, Hubens A, Verhaegu J. Campylobacter fetus as acause of acute cholecystitis. Br J Surg 73: 46, 1997.

17. Douketis J, Low DE. Campylobacter fetus cholangitis and bacteremia. Can Med Assoc J 141: 925-926, 1989.

18. Taziauz P, Wahlen C, Drion S. An unusual cause of non-lithiasis acute cholecystitis: Campylobacter jejuni. J Chir (Paris) 128: 554$555,1991$.

19. Gerritsen van der Hoop A, Veringa EM. Cholecystitis caused by Campylobacter jejuni. Clin Infect Dis 17: 133, 1993.

20. Lepe JA, Guadalajara J. Acute cholecystitis caused by Campylobacter jejuni. Enferm Infecc Microbial Clin 12: 364-365, 1994 (in Spanish).

21. Landau Z, Agmon NL, Argas D, Arcavi L, Simon D, Miskin A. Acute cholecystitis caused by Campylobacter jejuni. Isr J Med Sci 31: 696-697, 1995.

22. Takatsu M, Ichiyama S, Nada T, et al. Campylobacter fetus subsp. fetus cholecystitis in a patient with advanced hepatocellular carcinoma. Scand J Infect Dis 29: 197-198, 1997.

23. Drion S, Wahlen C, Taziaux P. Isolation of Campylobacter jejuni from the bile of cholecystic patient. J Clin Microbiol 26: 21932194, 1988.

24. Alvarez OA, Vanegas F, Maze GL, Gross GW, Lee M. Polymicrobial cholangitis and liver abscess in a patient with the acquired immunodeficiency syndrome. South Med J 93: 232-234, 2000.

25. Dakdouki GK, Araj GF, Hussein M. Campylobacter jejuni: unusual cause of cholecystitis with lithiasis. Case report and literature review. Clin Microbiol Infect 9: 970-972, 2003.

26. Udayakumar D, Sanaullah M. Campylobacter cholecystitis. Int J Med Sci 6: 374-375, 2009.

27. Vaughan-Shaw PG, Rees JR, White D, Burgess P. Campylobacter jejuni cholecystitis: a rare but significant clinical entity. BMJ Case Rep 2010: bcr1020092365, 2010. 
28. Suzuki J, Sugiyama T, Ito K, et al. Campylobacter showae bacteremia with cholangitis. J Infect Chemother 19: 960-963, 2012.

29. Gupta A, Tse L. Successful conservative management of campylobacter cholecystitis occurring post-chemotherapy and rituximab: a rare disease entity. N Z Med J 128: 110-112, 2015.

30. Huang T, Bass JA, Williams RD. The significance of biliary pressure in cholangitis. Arch Surg 98: 629-632, 1969.

31. Pacanowski J, Lalande V, Lacombe K, et al.; CAMPYL Study
Group. Campylobacter bacteremia: clinical features and factors associated with fatal outcome. Clin Infect Dis 47: 790-796, 2008.

The Internal Medicine is an Open Access journal distributed under the Creative Commons Attribution-NonCommercial-NoDerivatives 4.0 International License. To view the details of this license, please visit (https://creativecommons.org/licenses/ by-nc-nd/4.0/).

(C) 2021 The Japanese Society of Internal Medicine Intern Med 60: 3737-3741, 2021 